\title{
Correction to: Review: Observation of Majorana Bound States at a Free Surface of ${ }^{3} \mathrm{He}-\mathrm{B}$
}

\author{
Hiroki Ikegami $^{1}$ (D) Kimitoshi Kono ${ }^{1,2}$ (D)
}

Published online: 9 February 2022

(c) The Author(s) 2022

\section{Correction to: Journal of Low Temperature Physics (2019) 195:343-357 https://doi.org/10.1007/s10909-018-2069-y}

The article "Review: Observation of Majorana Bound States at a Free Surface of ${ }^{3} \mathrm{He}-$ B", written by Hiroki Ikegami, Kimitoshi Kono, was originally published electronically on the publisher's internet portal on 11 September 2018 without open access. With the author(s)' decision to opt for Open Choice the copyright of the article changed on 7 January 2022 to (C) The Author(s) 2018 and the article is forthwith distributed under a Creative Commons Attribution 4.0 International License, which permits use, sharing, adaptation, distribution and reproduction in any medium or format, as long as you give appropriate credit to the original author(s) and the source, provide a link to the Creative Commons licence, and indicate if changes were made. The images or other third party material in this article are included in the article's Creative Commons licence, unless indicated otherwise in a credit line to the material. If material is not included in the article's Creative Commons licence and your intended use is not permitted by statutory regulation or exceeds the permitted use, you will need to obtain permission directly from the copyright holder. To view a copy of this licence, visit http://creativecommons.org/licenses/by/4.0.

The original article has been corrected.

The original article can be found online at https://doi.org/10.1007/s10909-018-2069-y.

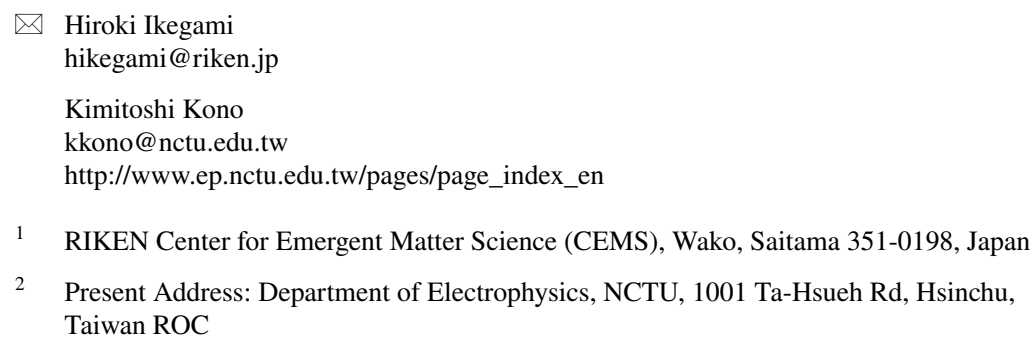


Open Access This article is licensed under a Creative Commons Attribution 4.0 International License, which permits use, sharing, adaptation, distribution and reproduction in any medium or format, as long as you give appropriate credit to the original author(s) and the source, provide a link to the Creative Commons licence, and indicate if changes were made. The images or other third party material in this article are included in the article's Creative Commons licence, unless indicated otherwise in a credit line to the material. If material is not included in the article's Creative Commons licence and your intended use is not permitted by statutory regulation or exceeds the permitted use, you will need to obtain permission directly from the copyright holder. To view a copy of this licence, visit http://creativecommons.org/ licenses/by/4.0/.

Publisher's Note Springer Nature remains neutral with regard to jurisdictional claims in published maps and institutional affiliations. 